\title{
Study on Effective Teaching of Higher Education
}

\author{
Min ZHU \\ Wuhan Textile University, Wuhan, China
}

\begin{abstract}
The article explains effective teaching of higher education from source, purpose, significance, implementation approach. The goal of effective teaching of higher education is to facilitate college student with independent construction.
\end{abstract}

KEYWORD: Effective Teaching; Higher Education

\section{SOURCE, PURPOSE AND SIGNIFICANCE OF EFFECTIVE TEACHING}

The concept of effective teaching originates from the western Scientific Movement in Education which was happened in the first 50 years of the $20^{\text {th }}$ century. Especially, this concept appeared frequently after the Efficiency Movement which was affected by both the American Pragmatism Philosophy and Behaviorism Psychology. This attracted great attention of personnel of all over the world who engaged in the same field. Effective teaching: it refers to the teaching that is no lower than the average level within certain time and space limits under the precondition of meeting the requirements for positive value construction of both the times and individuals. The core element of effective teaching is the benefit of teaching, namely, what kind of teaching is effective and is the teaching at highefficiency, low-efficiency, or no-efficiency status? Scholars from all over the world think that the effective teaching which takes class teaching as the core mainly studies the environment variable (characteristics of the study environment that have certain effect on the success or failure of study), process variable (various factors of class behaviors between teachers and students, study tasks, and study act that have certain affect on study results), and result variable (education results that the teachers expect, the teaching plan is based on, and can be scaled by objective and standard of effective teaching), etc. In specific study, two strategies are adopted: the first strategy is to study by combining the process variable and result variable, and simply research the relation between the process variable and result variable; and the second strategy is to only study the process variable, and on this basis, focus on the evaluation standard on effective teaching. However, the study on class teaching model of effective teaching and the study on behaviors are only started in domestic area. Especially, the study on effective teaching model of class teaching hasn't been started yet and is urgently needed to be solved.

The study on efficiency of class teaching is applied with modern education and psychology achievements, emphasizes interaction of teachers and students, and focuses on communication between teachers and students, and information exchange between teachers and students, and among students. It forms a real "study community" in the aim of reaching the goals of co-study, share, and coprogress. And the role - the leading actor (monodrama actor) that the teacher used to play turns out to be "Chief among all in equality"; then the traditional knowledge conveyor turns to be promoter of modern student development. Meanwhile, teachers exert their advantages during the process of conducting students to construct the subject knowledge system, and form effective teaching model that meets scientific and practical requirements and is also featured in rich characteristics.

\section{IMPLEMENTATION APPROACH OF EFFECTIVE TEACHING}

Cyxomjnhcknn once said that, "If the student fails to make even a tiny step forward on the road of mastering knowledge, then, it would be a useless 
class to him. And non-effective labor is the biggest potential danger that all teachers and students face to." "Effective class" is the permanent pursue of all our education practicers. Then, as a teacher, how to realize effective teaching?

(1) Effectiveness of class teaching depends on the effectiveness of class teaching objective for it restricts the progress and development of the class. Teaching objectives after-class shall be diversified. They shall not only focus on students' mastering of fundamental knowledge and skills, but shall also focus on the study process and method of students, as well as their emotion, attitude, and values. Therefore, the three elements of knowledge and skills, process and method, and emotion, attitude and values shall be completely integrated in teaching. This is the real significance of promoting the overall development of students. Effectiveness of students is represented in the point that whether the students positively participate in the study process and whether the students get progress and development on original basis. And the effectiveness of teachers is represented in the point that whether the initiative of study and construction of all students can be inspired or not. Therefore, before preparing for lessons, teachers shall read through the teaching materials and teachers' books carefully to master the teaching content objectives and material formulating features, thus to combine with the practical students' status to formulate feasible class teaching objectives. The formulated teaching objectives shall be specific and feasible. Too low or too high objectives would make the students loss interest on study. And the teachers shall pay attention to the process teaching to change the status that students are forced to accept knowledge.

(2) Teachers shall also pursue for high quality. Teacher is the designer, executor, and manager of class teaching, the conductor, organizer and helper for students' learning activity. The largest dissatisfaction of students is that their interests cannot be fully mobilized; the classroom atmosphere is rigid, which is called as cramming method by students. Teachers ignore students' subjective desire to participate, also ignore the cultivation and expansion on the unobservable subject spirit world. Let alone other matters. Such approach makes it impossible for students to form subjective value psychologically on knowledge, thus affecting learning effect. Therefore, to carry out effective teaching, teachers shall pay attention to the following three points: firstly, it is to inspire students' motivation on learning. Secondly, it is to indicate the targets students shall achieve and the contents to learn, that is to inform students of what to learn and what degree they shall reach. Only in this way, students can consciously participate.
Thirdly, it is to adopt the way for students' easy understanding, namely, teach students in accordance of their aptitude. For example, the verbal expression and speed shall be understood by the students. Or, teachers can apply in the methods, for example, repetition, explain the profound in simple terms, be cadence, emphasize with blackboard-writing and use chalks of different colors in blackboard-writing to make the focal points stand out and so on.

(3) To realize effective teaching, teachers shall create a relaxed and harmonious learning environment for students. A good, harmonious and democratic relationship shall be established between teachers and students. Teachers shall become the guider and organizer to lead students to pursue, absorb and use knowledge, and become their friend who can understand their views, ideas and emotional characteristics. In such way, students will be able to go into the teaching process with great enthusiasm and full emotions. Then, the classroom atmosphere will be unusually active. The students can also be free and dare to express their views.

(4) Effective teaching shall be natural and normal teaching. Such courses may not reach the result of the initial presuppose, but there are input of teachers and students in emotion, wisdom, thinking and ability in the class. And there are also mutual discussion, thought collision, the composition of the teachers and students, and the process of generating a lot of new things. This is the informative and real teaching.

(5) Persist in teaching reflection. Persist in teaching reflection can improve the teacher's innovation awareness, professional level and achieve effective classroom teaching. Reflection generates from problems. The teachers' understanding of what is effective, low effective and inefficient teaching is fuzzy, not that specific or profound. In this case, persist in teaching reflection, allow the teachers to examine, reflect and question their own teaching, and find out the low effective and inefficient problems in teaching, conduct the research and discussion and finally put forward new concept, new method and new measures to gradually improve the effective teaching. In my opinion, to improve the ability of teaching reflection, it is important to pay attention to the "depth" of the reflection quality, namely, reflection shall be deeply, highly, innovative and flexible. Practice shows that it is impossible for a teacher without reflection to convert into the research-based and reflective teacher in curriculum reform. His experience is also narrow and his professional development will also be restricted, cannot adapt to the requirement of new curriculum reform. 


\section{SUMMARY ON EFFECTIVE TEACHING PRACTICE}

The ultimate goal of education is to facilitate student with independent construction. To achieve such goal, effective teaching shall be realized. The classroom is the place to realize education and teaching reform direction and arrival. But to really achieve the effectiveness of classroom teaching, there are many problems waiting for us to solve. There are many ways and methods to improve the classroom teaching effect, but any way is not achieved overnight, it needs teachers to use advanced teaching concept to guide their own teaching practice, and consistently run throughout the inside and outside of the classroom.

\section{REFERENCES}

[1] Liu Guiqiu. New Exploration on the Concept of Effective Teaching-Effective Teaching under Comprehensive Effective Teaching Value. Course Material and Teaching Method, 2008(09).

[2] Hao Wenwu. Effective Teaching Methods in the Realization of Three-dimensional Teaching Target Unification. Education Research, 2009 (01).

[3] Wang Xihua. Exploration on the "Cooperative Teaching between Teachers and Students" in Effective Teaching Mode. Modern Education Science, 2009 (01).

[4] Liu Wanhai. Teachers' Teaching Responsibility in "Effective Teaching". Education Development Research, 2009 (Z2). 